\title{
Factors Effecting Long-term Survival in Operated Large Cell Carcinoma of the Lung
}

\author{
Soner GURSOY, Ozan USLUER, Ahmet UCVET, Serkan YAZGAN, Banu YOLDAS, Tarik YAGCI
}

Dr. Suat Seren Chest Disease and Thoracic Surgery Training and Research Hospital, Department of Thoracic Surgery, Izmir, TURKEY

\begin{abstract}
The aim of this study was to evaluate of the results of the treatment of patients who underwent surgery due to large cell lung carcinoma and to analyze the variables affecting the survival outcomes. Pulmonary resections were performed on 1221 patients with pathological stages I, II, III non-small cell lung cancer between January 2003 and January 2013. A total of 85 patients (7\%) who were histologically diagnosed with large cell lung carcinoma and 10 patients were excluded from the study because of operative mortality, incomplete resection, and follow-up. The records of 75 patients undergoing complete resection were evaluated in terms of demographics, survival rates, and variables affecting the survival. Seventy-one (94.7\%) male and four (5.3\%) female patients with a mean age of $58.1 \pm 9.8$ years (range: 38 to 76 years) were included in the study. Neoadjuvant treatment was administered to four (5.3\%) patients. Lobectomy was performed on $53(70.7 \%)$ patients and 28 (37.3\%) had neuroendocrine differentiation (NED) in their tumors. Median and five-year survival rates were 80.8 months and $51.1 \%$, respectively in a mean follow-up period of $34.9 \pm 27.7$ months (range: 2.4 to 91.6 months). Five-year survival rates in the groups with and without neuroendocrine differentiation were $37.8 \%$ and $57.9 \%$, respectively, with no statistically significant difference between the groups $(p=0.53)$. The absence of lymph node metastasis and adjuvant treatment had positive effects on survival in patients with large cell lung carcinoma who underwent resection. Although not statistically significant, neuroendocrine differentiation led to a lower survival rates.
\end{abstract}

Keywords: Large cell lung carcinoma, Neuroendocrine differentiation, Surgery, Survival

ÖZET

Opere Edilmiş Büyük Hücreli Akciğer Karsinomunda Uzun Dönem Sağkalımı Etkileyen Faktörler

Bu çalışmada büyük hücreli akciğer kanseri nedeniyle cerrahi tedavi uygulanan hastaların tedavi sonuçlarının analiz edilmesi ve sağkalım sonuçlarına etkili değişkenlerin araştıııması amaçlanmıştır. Ocak 2003-2013 arasında 1221 hastaya evre I, II ve III küçük hücreli dışı akciğer kanseri nedeni ile lobektomi veya pnömonektomi uygulandı. Bu hastalardan 85'i (\%7) histolojik olarak büyük hücreli karsinom tanısı aldı ve 10 hasta operatif mortalite, inkomplet rezeksiyon ve inkomplet izlem nedeniyle çalışma dışı bırakıldı. Komplet rezeksiyon uygulanmış 75 hastanın tıbbi kayıtları, demografik özellikleri ve sağkalım oranları ile sağkalıma etkili değişkenler açıından

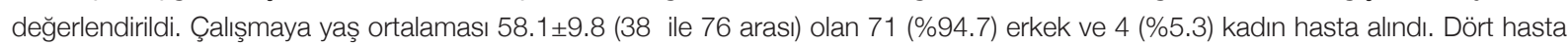
(\%5.3) neoadjuvan tedavi aldı. Lobektomi uygulanan 53 (\%70.7) hasta bulunuyordu ve 28 (\%37.3) hastada nöroendokrin diferansi-

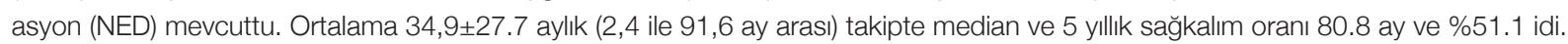
Nöroendokrin diferansiasyon saptanan ve saptanmayanlarda 5 yıllık sağkalım oranları sırası ile \%37.8 ve \%57.9 idi ve arada istatistiksel olarak anlamlı bir fark saptanmadı ( $p=0.53$ ). Bu çalışmada rezeke edilen büyük hücreli akciğer karsinomlu hastalarda, lenf bezi metastazının olmaması ve adjuvan tedavi uygulanımının sağkalıma etkisinin daha iyi olduğu saptandı. İstatistiksel olarak anlamlı olmasa da nöroendokrin diferansiasyon, daha kötü bir sağkalım oranı göstermiştir. Ancak lokal yayııım izlenmeyen ve adjuvan tedavi uygulanan hastalarda sağkalım sonuçlarının daha iyi olması beklenebilir.

Anahtar Kelimeler: Büyük hücreli akciğer karsinomu, Nöroendokrin diferansiasyon, Cerrahi, Sağkalım 


\section{INTRODUCTION}

The term large cell lung carcinoma (LCC) includes a group of tumors that are not included in the other classifications of lung carcinoma, due to histopathological specifications. Its frequency among all the lung cancers is reported to be $9 \% .{ }^{1}$ Microscopically, they are tumors including organoid and trabecular cells and have high mitotic activity and diffuse necrotic areas. ${ }^{2}$ In addition to the histopathological differences, neuroendocrine differentiation (NED) can also be observed in these tumors in which the response to treatment and prognosis are also unique. The presence of NED in large cell carcinomas places them in the group of neuroendocrine tumors of the lungs. ${ }^{3}$ The prognosis in those patients with large cell neuroendocrine carcinoma (LCNEC) of the lungs is considered to be between small cell lung cancer (SCLC) and atypical carcinoid tumors of this group. LCCs have been treated similarly to NSCLC; however, a controversial issue in recent years is whether the prognosis of these tumors are close to the prognosis of small cell lung cancer in case NED is detected in these tumors. Therefore, it is important for this group of patients to benefit from complete lung resections. The current study analyzed patients who underwent surgical resection due to large cell lung cancer, the frequency of neuroendocrine differentiation and its effect on survival, together with other factors.

\section{PATIENTS AND METHODS}

A total of 1221 patients who underwent surgery for non-small cell lung cancer (NSCLC) between 2003 and 2013 were retrospectively reviewed. There were 85 patients $(7 \%)$ with a histopathological diagnosis of large cell lung cancer (LCC) among these patients. Ten patients were excluded from the study due to operative mortality, incomplete resection, and incomplete follow-up. Presence of neuroendocrine phenotype was confirmed with immunohistochemical staining methods in 28 out of 75 patients $(37.3 \%)$ and these patients were identified as the NED (+) group. The rest of the patients $(n=47 ; 62.7 \%)$ represented the NED (-) group. A diagnosis of large cell neuroendocrine carcinoma (LCNEC) was made when all WHO classification criteria were present in the histopathological examination.
Chest X-ray, computed tomography (CT), and fiber optic bronchoscopy were used for loco-regional assessment of lung cancer. Clinical N2 status was defined by the presence of a lymph node measuring greater than $1 \mathrm{~cm}$ in the short axis diameter on CT. PET/CT scan was used for distant organ metastasis after 2006 and invasive mediastinal staging (cervical mediastinoscopy) was performed to detect possible mediastinal lymph node metastases according to the scanning results. The pulmonary function was routinely evaluated using spirometry and arterial blood gas analysis. Carbon monoxide diffusion capacity and quantitative ventilation perfusion lung scan was done on patients with an impaired pulmonary reserve (estimated post-resection FEV1 of less than $60 \%$ ). All patients underwent complete resection (lobectomy, bilobectomy, sleeve lobectomy, or pneumonectomy). Segmentectomy was not performed.

The patients were evaluated in two groups in terms of demographics, preoperative and postoperative management, and survival rates and variables affecting the following parameters: NED (+) group with observation of neuroendocrine differentiation and the NED (-) group without observation of neuroendocrine differentiation.

\section{Statistics}

The statistical analysis was conducted using the SPSS package (SPSS, Chicago, IL). Survival was analyzed using the Kaplan-Meier method and the curves were compared using a log-rank test. Multivariate analysis was performed using the Cox proportional hazard model. Frequency comparisons were carried out by Pearson's chi-square test and Fisher's exact test. Results were considered significant at $\mathrm{p}<0.05$.

\section{RESULTS}

Seventy-five patients included 71 males and 4 females, indicating a significantly greater number of male patients. The average age at presentation was $58.1 \pm 9.8$ years (range: 38 to 76 years). Seventy-one patients $(94.7 \%)$ were current or former smokers. Demographic features of the patients [age, gender, the application of neoadjuvant or adjuvant therapy, 
International Journal of Hematology and Oncology

Table 1. Characteristics of the two groups of patients (depending on NED)

\begin{tabular}{|c|c|c|c|c|c|c|c|}
\hline \multirow[t]{2}{*}{ Variables } & \multicolumn{2}{|c|}{ Total } & \multicolumn{2}{|c|}{ NED (-) group } & \multicolumn{2}{|c|}{ NED (+) group } & \multirow[t]{2}{*}{$p$-value } \\
\hline & n & $\%$ & $\mathbf{n}$ & $\%$ & $\mathbf{n}$ & $\%$ & \\
\hline Total & 75 & 100 & 47 & 62.7 & 28 & 37.3 & - \\
\hline \multicolumn{8}{|l|}{ Sex } \\
\hline Male & 71 & 94.7 & 46 & 97.9 & 25 & 89.3 & 0.14 \\
\hline Female & 4 & 5.3 & 1 & 2.1 & 3 & 10.7 & \\
\hline \multicolumn{8}{|l|}{ Age } \\
\hline$\leq 60$ & 39 & 52 & 24 & 51.1 & 15 & 53.6 & 1 \\
\hline$>60$ & 36 & 48 & 23 & 48.9 & 13 & 46.4 & \\
\hline \multicolumn{8}{|l|}{ Neoadjuvant therapy } \\
\hline Absent & 71 & 94.7 & 45 & 95.7 & 26 & 92.9 & 0.63 \\
\hline Present & 4 & 5.3 & 2 & 4.3 & 2 & 7.1 & \\
\hline \multicolumn{8}{|l|}{ Operation type } \\
\hline Lobectomy & 53 & 70.7 & 33 & 70.2 & 20 & 71.4 & 0.35 \\
\hline Sleeve lobectomy & 10 & 13.3 & 8 & 17 & 2 & 7.1 & \\
\hline Pneumonectomy & 12 & 16.0 & 6 & 12.8 & 6 & 21.4 & \\
\hline \multicolumn{8}{|l|}{ Tumor type } \\
\hline$\leq 3 \mathrm{~cm}$ & 19 & 25.3 & 9 & 19.1 & 10 & 35.8 & 0.26 \\
\hline $3-5 \mathrm{~cm}$ & 26 & 34.7 & 17 & 36.2 & 9 & 32.1 & \\
\hline$>5 \mathrm{~cm}$ & 30 & 40 & 21 & 44.7 & 9 & 32.1 & \\
\hline \multicolumn{8}{|l|}{$p-T$} \\
\hline । & 13 & 17.3 & 7 & 14.9 & 6 & 21.4 & 0.74 \\
\hline$\|$ & 41 & 54.7 & 27 & 57.4 & 14 & 50 & \\
\hline III & 21 & 28 & 13 & 27.7 & 8 & 28.6 & \\
\hline \multicolumn{8}{|l|}{$\mathrm{p}-\mathrm{N}$} \\
\hline 0 & 54 & 72 & 34 & 72.3 & 20 & 71.4 & 0.56 \\
\hline 1 & 10 & 13.1 & 5 & 10.6 & 5 & 17.9 & \\
\hline 2 & 11 & 14.7 & 8 & 17 & 3 & 10.7 & \\
\hline \multicolumn{8}{|l|}{ p-stage } \\
\hline 1 & 27 & 36 & 17 & 36.2 & 10 & 35.7 & 0.95 \\
\hline 2 & 28 & 37.3 & 18 & 38.3 & 10 & 35.7 & \\
\hline 3 & 20 & 26.7 & 12 & 25.5 & 8 & 28.6 & \\
\hline \multicolumn{8}{|l|}{ Smoking } \\
\hline Absent & 4 & 5.3 & 4 & 8.5 & 0 & 0 & 0.28 \\
\hline Present & 71 & 94.7 & 43 & 91.5 & 28 & 100 & \\
\hline \multicolumn{8}{|l|}{ Adjuvant therapy } \\
\hline Absent & 52 & 69.3 & 33 & 70.2 & 19 & 67.9 & 1 \\
\hline Present & 23 & 30.7 & 14 & 29.8 & 9 & 32.1 & \\
\hline
\end{tabular}




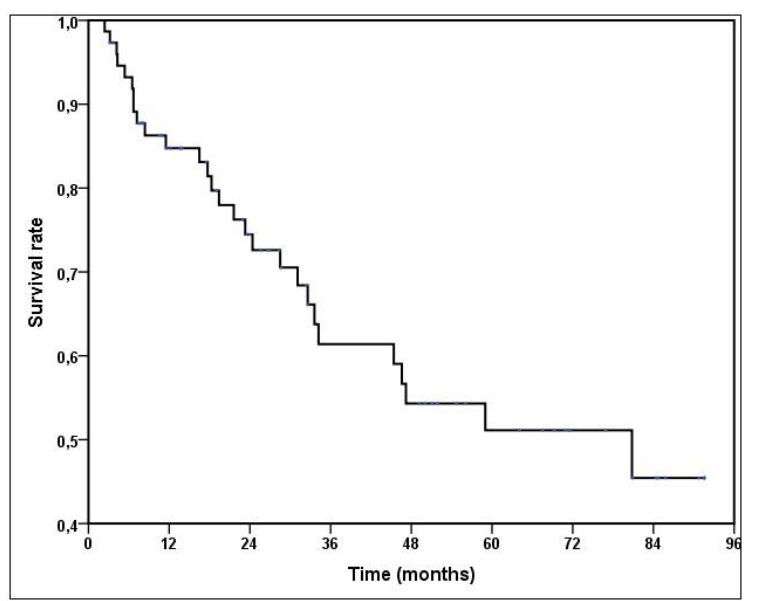

Figure 1. Kaplan-Meier five-year survival estimates for all 75 patients

operation type (lobectomy, sleeve lobectomy, or pneumonectomy), tumor diameter, pathological stage, and smoking] are given in Table 1. An en bloc resection of the chest wall was additionally performed in four lobectomy cases. PET/CT was obtained in $34(47 \%)$ cases and $10(13 \%)$ cases underwent mediastinoscopy for lymph node staging according to the results.

Endobronchial lesions were seen in 16 cases (21\%) in the fiber optic bronchoscopy (FOB). The endobronchial localization was as follows; in three (4\%) cases the tumor was in the main bronchus less than $2 \mathrm{~cm}$ distal to the carina, but without involvement of the carina, in three (4\%) cases the tumor involved the main bronchus, but was $2 \mathrm{~cm}$ or more

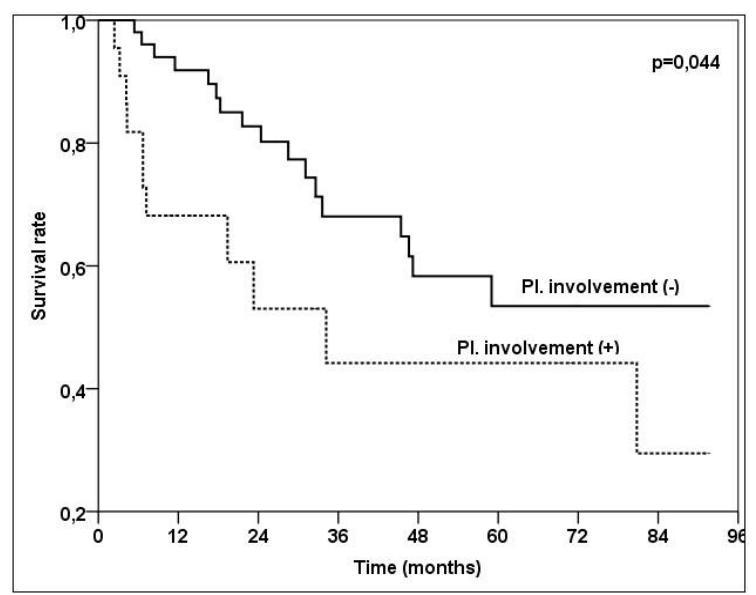

Figure 3. Five-year survival curves in patients with (dashed line) and without (straight line) pleural metastasis $(p=0.044)$

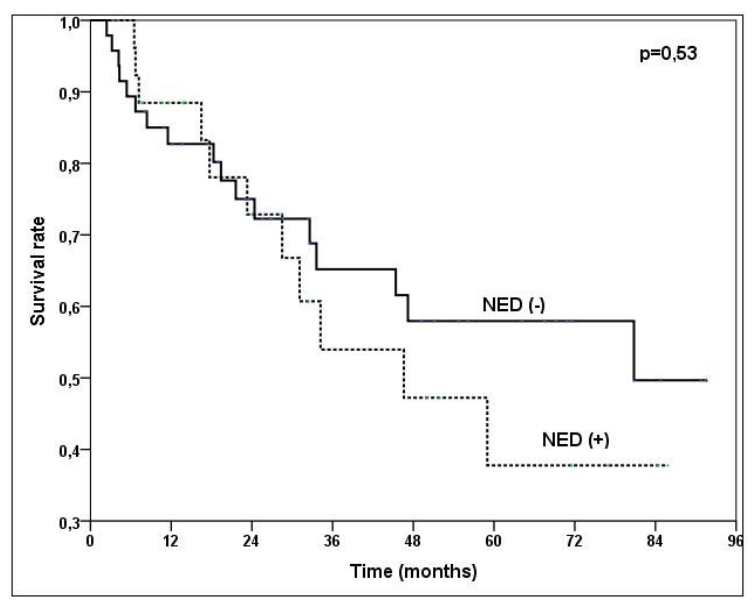

Figure 2. Five-year survival curves in patients with NED (neuroendocrine differentiation) (dashed line) and without NED (straight line) $(p=0.53)$.

distal to the carina, in four $(5 \%)$ cases the tumor was in the proximal lobar bronchus, in six $(8 \%)$ cases the tumor was in the segmental bronchus, and in $59(79 \%)$ cases the tumor was peripherally located.

Platinum-based neoadjuvant chemotherapy was administered to only four $(5.3 \%)$ cases due to mediastinal lymph node metastasis, and postoperative chemotherapy (CT) and/or radiotherapy (RT) was administered to $23(30.7 \%$ ) cases (CT in 17 cases, $\mathrm{RT}$ in five cases, and $\mathrm{CT}+\mathrm{RT}$ in one case).

Overall survival curve for the 75 accurately staged patients with complete resection was $51.1 \%$ at five years, as shown in Figure 1. In addition, survival curves were created for neuroendocrine differenti-

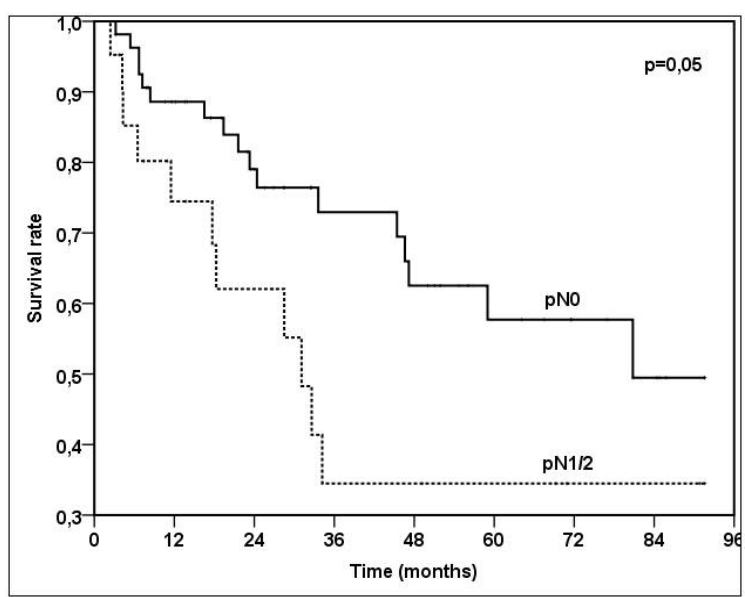

Figure 4. Five-year survival curves in patients with (dashed line) and without (straight line) lymph node involvement ( $p=$ 0.05) 
International Journal of Hematology and Oncology

Table 2. Univariate analyses of prognostic factors in surgically resected large cell carcinoma of the lung

\begin{tabular}{|c|c|c|c|c|}
\hline Variables & $\begin{array}{l}\text { 5-year survival. } \\
\%\end{array}$ & $\begin{array}{l}\text { Mean survival } \\
\text { (months } \pm S D \text { ) }\end{array}$ & Conifidence interval & p-value \\
\hline Total & 51.1 & $58.38 \pm 4.69$ & $49.18-67.57$ & - \\
\hline Disease-free & 50.8 & $55.8 \pm 5.03$ & $45.94-65.65$ & - \\
\hline \multicolumn{5}{|l|}{ Sex } \\
\hline Male & 55.9 & $60 \pm 4.88$ & $50.45-69.55$ & 0.19 \\
\hline Female & 0 & $41.3 \pm 12.04$ & $17.69-64.91$ & \\
\hline \multicolumn{5}{|l|}{ Age } \\
\hline$\leq 60$ & 47.3 & $57.09 \pm 6.84$ & $43.69-70.49$ & 0.95 \\
\hline$>60$ & 54.7 & $59 \pm 6.5$ & $46.27-71.73$ & \\
\hline \multicolumn{5}{|l|}{ Neoadjuvant therapy } \\
\hline Absent & 51.5 & $58.73 \pm 4.73$ & $49.46-68.00$ & 0.54 \\
\hline Present & 75 & $12.05 \pm 1.60$ & $8.91-15.19$ & \\
\hline \multicolumn{5}{|l|}{ Operation type } \\
\hline Lobectomy & 56.3 & $63.7 \pm 5.5$ & $52.8-74.5$ & 0.12 \\
\hline Sleeve lobectomy & 53.3 & $52 \pm 13.3$ & $26.8-78.7$ & \\
\hline Pneumonectomy & 23.6 & $35.7 \pm 7.5$ & $21.1-50.3$ & \\
\hline \multicolumn{5}{|l|}{ Tumor size } \\
\hline$\leq 3 \mathrm{~cm}$ & 44 & $53.04 \pm 7.77$ & $37.81-68.28$ & 0.74 \\
\hline $3-5 \mathrm{~cm}$ & 62.6 & $65.22 \pm 8.26$ & $49.03-81.41$ & \\
\hline$>5 \mathrm{~cm}$ & 46.8 & $54.64 \pm 7.04$ & $40.84-68.44$ & \\
\hline \multicolumn{5}{|l|}{ p-Tumor } \\
\hline 1 & 34.7 & $51.39 \pm 9.06$ & $33.63-69.14$ & 0.69 \\
\hline 2 & 55.6 & $62.33 \pm 6.34$ & $49.90-74.76$ & \\
\hline 3 & 50.8 & $52.76 \pm 8.91$ & $35.30-70.22$ & \\
\hline \multicolumn{5}{|l|}{ p-Node } \\
\hline 0 & 57.7 & $64.1 \pm 5.3$ & $53.80-74.42$ & 0.05 \\
\hline $1 / 2$ & 34.5 & $52.3 \pm 11.6$ & $29.6-75.0$ & \\
\hline \multicolumn{5}{|l|}{ p-stage } \\
\hline 1 & 52.5 & $57.81 \pm 6.43$ & $45.20-70.41$ & 0.29 \\
\hline 2 & 55 & $60.97 \pm 7.06$ & $47.15-74.80$ & \\
\hline 3 & 40.3 & $46.92 \pm 10.16$ & $27.01-66.83$ & \\
\hline \multicolumn{5}{|l|}{ NED } \\
\hline Absent & 57.9 & $61.08 \pm 5.79$ & $49.74-72.42$ & 0.53 \\
\hline Present & 37.8 & $50.83 \pm 7.15$ & $36.81-64.84$ & \\
\hline \multicolumn{5}{|l|}{ Pleural metastasis } \\
\hline Absent & 53.5 & $63.14 \pm 5.31$ & $52.73-73.55$ & 0.044 \\
\hline Present & 44.2 & $46.7 \pm 9.3$ & $28.4-65.0$ & \\
\hline Present & 52.8 & $58.93 \pm 9.32$ & $40.67-77.19$ & \\
\hline
\end{tabular}


International Journal of Hematology and Oncology

Table 3. Multivariate analyses of prognostic factors in surgically resected large cell carcinoma of the lung

Variable

P-node metastasis, N0 vs. N1 and N2

Operation type, lobectomy, sleeve lobectomy vs. pneumonectomy

Neoadjuvant chemotherapy, present vs. absent

Adjuvant chemotherapy, present vs. absent

Pleural metastasis, present vs. absent

P-stage, P-stage I vs. P-stage || and P-stage III

NED, present vs. absent p-value

0.027

0.52

0.56

0.029

0.14

0.99

0.53

p-stage: pathological stage. NED: Neuroendocrine differantion.

ation (Figure 2), pleural metastasis (Figure 3), and lymph node metastasis (Figures 4).

The influence of age, gender, neoadjuvant therapy, operation type, tumor size, pathologic $\mathrm{T}$, pathologic $\mathrm{N}$, pathologic stage, and neuroendocrine differentiation were evaluated by univariate analysis (Table 2). The multivariate analysis in our series identified predictors of survival (Table 3).

\section{Follow-up}

Four patients $(5 \%)$ dropped out of the follow-up during the study period. The follow-up for this group ranged from 2.4 months to 105.6 months. The median follow-up time was $34.9 \pm 27.7$ months. Twelve patients $(16 \%)$ died of causes other than neoplastic disease, and 17 patients $(23 \%)$ died of metastatic spread. Four (5\%) loco-regional recurrences were noted.

\section{DISCUSSION}

Pleural metastasis $(\mathrm{p}=0.05)$ and lymph node metastasis $(p=0.044)$ were associated with poorer overall survival for large cell carcinoma (LCC) after complete resection in univariate analyses, but no other variables had an effect on survival in these patients. In addition, the multivariate analysis also showed that lymph node metastasis had a negative effect $(p=0.027)$ where adjuvant therapy $(p=$
0.029) positively affected survival of LCC patients. None of other variables were statistically significant. The median and five-year survival was much higher in the NED (-) group compared to the NED (+) group $(57.9 \%$ versus $37.8 \%$ and 80.8 months versus 46.6 months, respectively); however, it is noteworthy that we found no significant difference in survival between patients with NED (+) group and the NED (-) group.

Following the classification of the neuroendocrine tumors of the lungs in the 1970s as typical carcinoid tumors, atypical carcinoid tumors and small cell carcinomas ${ }^{4}$, Travis et al. ${ }^{5}$ introduced the concept of large cell neuroendocrine carcinoma (LCNEC) as a subgroup of neuroendocrine tumors in 1991. LCNEC was classified in an intermediate position between atypical carcinoid and small cell lung carcinoma according to its clinically aggressive behavior. ${ }^{6}$ Finally, it was defined as a variant of large cell carcinoma in 1999 and later in 2004 by the World Health Organization (WHO) ${ }^{3,7}$ According to these studies, the main criteria for diagnosing LCNEC are: (A) large cell morphology; (B) high mitotic rate of more than 11 or greater/10 high power fields; and (C) the detection of neuroendocrine morphology and immunohistochemical markers. However, it became clear that the clinical and biological features of LCNEC are similar to those of small cell lung carcinoma (SCLC), and the differential diagnosis between LCNEC and SCLC is quite difficult in some cases. ${ }^{8,9,10}$ 
Park et al. demonstrated that the preoperative diagnosis for LCC is sometimes difficult because of the small sample obtained in lung biopsies. ${ }^{11}$ Larger surgical specimens often yield more information, and the diagnosis often changes to adenocarcinoma or squamous cell carcinoma. It is difficult to distinguish a poorly differentiated squamous cell carcinoma or adenocarcinoma preoperatively because of the indefinite diagnosis criteria. In this study, preoperative fine-needle aspiration biopsy was inconclusive for tumor type in 16 out of 75 patients (21\%) and a definitive diagnosis was possible only in the perioperative period. Preoperative cisplatin-based chemotherapy was administered in four cases $(5.3 \%)$ in this study and all of them responded to the treatment. However, the clinical characteristics and optimal treatment of large cell carcinomas (LCC) have not yet been clearly identified. Large series, especially on large cell carcinomas demonstrating neuroendocrine behavior, are rare.

The absence of large series in the literature is a serious problem in creating a definitive treatment strategy in LCC. A surgical approach to cases with these tumors was recommended to be similar to the cases with non-small cell lung cancers (NSCLC). ${ }^{12}$ In addition, according to the Guidelines of the National Comprehensive Cancer Network, the treatment of these tumors was suggested to be similar to non-small cell lung cancers. ${ }^{13}$ Many studies suggest a better prognosis be obtained with complete resection and systematic nodal dissection. ${ }^{14,15,16}$

The efficacy of cisplatin-based chemotherapy in patients with LCNEC and small cell carcinomas were found to be similar to the reported objective response of 50\%. ${ }^{17}$ Survival rates were demonstrated to be significantly increased with surgery and adjuvant therapy in an early stage LCNEC series $(n=73)$ of Iyoda et al. ${ }^{18}$ In the present study, on the other hand, adjuvant therapy was applied to the locally advanced cases. Although the group of patients receiving adjuvant therapy in his study $(\mathrm{n}=23 ; 31 \%)$ was at a more advanced stage of the disease, the five-year survival in this group was slightly higher compared to the group of early stage patients $(n=52,69 \%)$ who did not receive adjuvant therapy; however, the difference was not statistically significant $(52.8 \%$ vs. $49.8 \%$; $\mathrm{p}=0.75)$.
LCC is generally seen in men with a mean age in the sixth decade of life. ${ }^{14-18}$ The mean age was 63.7 years in a series of patients with LCNEC in a study of ten years' of experience reported by Paci et al. ${ }^{15}$ Males comprised $94.7 \%$ of the cases in the present series $(97.9 \%$ and $87.3 \%$ in the groups with NED $(-)$ and NED (+) cases, respectively). Overall mean age was 58.1 years (range: $38-76$ years); and was 58.4 years (range: $38-76$ years), and 57.5 (range: 41-73 years) in NED (-) and NED (+) cases, respectively.

A history of cigarette smoking is a specifically emphasized issue in the studies concerning cases with LCNEC. ${ }^{12,15,19,20}$ It is such a rare event that one case with LCNEC without a history of cigarette smoking was reported in a case report in the literature. ${ }^{22}$ In those cases, a mixed tumor is generally present. ${ }^{19,21,22}$ Takei et al. reported that $98 \%$ of their large LCNEC series of 87 cases were cigarette smokers. ${ }^{19}$ The history of cigarette smoking was positive in most of our cases (94.7\%); however, no mixed tumors were detected.

Symptoms of LCC are nonspecific, such as coughing and hemoptysis, which are also seen in other lung tumors. Findings such as flushing, wheezing, and diarrhea can be seen in cases with $\mathrm{NED}^{13}$; however, none of these symptoms were present in the NED (+) group of patients in this study.

An extremely rare incidence of endobronchial localization has been reported in some series. ${ }^{15,22}$ However, of 63 patients, no endoluminal lesions were seen in 31 cases $(49.2 \%)$ in the fiber optic bronchoscopy (FOB) (10). Park et al. detected a visible mass in the FOB in $38.4 \%$ of the patients who were diagnosed with LCC (10/26). ${ }^{11}$ We detected endobronchial lesions using fiber optic bronchoscopy in $21 \%(16 / 75)$ of the cases. Most of the 16 cases $(21 \%)$ with endobronchial lesions were in the NED (+) patient group $(n=10 ; 13 \%)$. In addition, since LCNECs generally have a peripheral localization, findings of post-obstruction are rare ${ }^{13,15,20}$ Endobronchial localization was detected in $16(21 \%)$ patients with post-obstruction atelectasis in only six (8\%) patients in this study. Four of these patients $(5 \%)$ were in the NED (+) group. Tumoral calcification was absent in all patients in preoperative CT. 
Mean five-year survival was reported to be $57 \%$ in a large series of LCNEC by Takei et al., while the figure was $51 \%$ in our series and $38 \%$ in patients with detected NED. ${ }^{19}$ Cases with LCNEC deserve much greater attention in the literature among the LCCs; however, the effects of NED positivity on survival with evaluation of all cases, as is the case in the current study, have not been extensively reported. A statistically significant effect of NED on survival was not found in the current study; however, some studies have reported its negative effect on survival. ${ }^{18-23}$

Lymph node involvement in the mediastinum was identified in $28 \%$ of the cases in a series by Takei et al. ${ }^{19}$ In the study of Iyoda et al., five-year survival was $51.7 \%$ for LCNEC, which was statistically lower than cases with LCC $(\mathrm{p}=0.0321) .{ }^{18} \mathrm{On}$ the other hand, the high mitotic activity in those cases of LCNEC was emphasized in that study. The five-year overall survival for resected LCNEC in different studies was $13-51 \% .^{10,15,19,23,24}$ Pathological N1 (five patients each in the NED (-) and NED (+) groups, respectively) and N2 (eight and three patients in the NED (-) and NED (+) groups, respectively) were detected in 10 and 11 patients, respectively. Overall survival in patients with $\mathrm{pN} 1$ and $\mathrm{pN} 2$ was $41.1 \%$ (60\% and $0 \%$ in the NED (-) and NED $(+)$ groups, respectively; $\mathrm{p}=0.42)$ and $28.9 \%$ (40\% and $0 \%$ in the NED (-) and NED (+) groups, respectively; $\mathrm{p}=0.40)$, respectively. Overall survival was $57.7 \%$ in cases with pN0 $(60.2 \%$ and $53.0 \%$ in the NED (-) and NED (+) groups, respectively; $\mathrm{p}=0.96)$.

Rates of pneumonectomy were reported to be between 2 and $23 \%$ in the studies performed. ${ }^{10,15,19,23,25}$ Lobectomy, sleeve lobectomy and pneumonectomy were performed in 53 (70.7\%), (13.3\%) and 16 (12\%) patients, respectively. The most common indication for pneumonectomy was fissure invasion (16/22 patients, $72.7 \%)$. There were no statistically significant differences in survival between the patients who underwent lobectomy and pneumonectomy $(\mathrm{p}=0.55)$.

The present study had several limitations. It was retrospective in design and involved a relatively small number of patients. Additionally, some of the patients did not undergo PET-CT scan. A prospec- tive study with a large number of patients and with well-defined inclusion and exclusion criteria could overcome these limitations.

In conclusion, neuroendocrine differentiation seemed to result in a decreased survival rate, although it was not statistically significant. The absence of lymph node metastasis and the application of adjuvant treatment were found to positively affect survival in patients with resected large cell carcinoma. Therefore, it is suggested that adjuvant treatment should be applied to these patients.

\section{REFERENCES}

1. Altekruse SF, Kosary CL, Krapcho M, et al. SEER Cancer Statistics Review, 1975-2007, National Cancer Institute. http://seer.cancer.gov/csr/1975_2007/. Access date: 5 April October 2015.

2. Shields TW. Patology of carcinoma of the lung. In: General Thoracic Surgery. Shields TW, LoCicero J, Ponn RB (eds). 6th edition. Philadelphia: Ed. Wippincot, Williams and Wilkins, 2005: 1455-80.

3. Brambilla E. WHO 1999 classification of lung cancers: a guided tour. Ann Pathol 19: 47-49, 1999.

4. Arrigoni MG, Woolner LB, Bernatz PE. Atypical carcinoid tumors of the lung. J Thorac Cardiovasc Surg 64: 413-421, 1972.

5. Travis WD, Colby TV, Corrin B, et al. World Health Organization International Histological Classification of Tumors. Histological typing of Lung and Pleural Tumors. 3rd edition. Berlin: Springer Verlag; 1999.

6. Rusch VW, Klimstra DS, Venkatraman ES. Molecular markers help to characterize neuroendocrine lung tumors. Ann Thorac Surg 62: 798-810, 1996.

7. Travis WD, Brambilla E, Muller-Hermelink HK, Harris CC. World Health Organization Classification of Tumours. Pathology and Genetics: Tumours of the Lung, Pleura, Thymus and Heart. Lyon: IARC Press; 2004.

8. Den Bakker MA, Willemsen S, Grunberg K, et al. Small cell carcinoma of the lung and large cell neuroendocrine carcinoma interobserver variability. Histopathology 56: 356-363, 2010.

9. Doddoli C, Barlesi F, Chetaille B, et al. Large cell neuroendocrine carcinoma of the lung: An aggressive disease potentially treatable with surgery. Ann Thorac Surg 77: 1168-1172, 2004.

10. Fournel L, Falcoz PE, Alifano M, et al. Surgical management of pulmonary large cell neuroendocrine carcinomas: a 10year experience. Eur J Cardiothorac Surg 43: 111-114, 2013. 
11. Park MS, Shin DH, Chung KY, et al. Clinical features of bronchogenic large cell carcinoma confirmed by surgical resection. Korean J Intern Med 18: 212-19, 2003.

12. Ohara G, Satoh H, Kikuchi N, lijima T, Ohtsuka M. A longterm survivor with pulmonary large-cell neuroendocrine carcinoma. Respir Med 101: 2425-2427, 2007.

13. Gridelli C, Rossi A, Airoma G, et al. Treatment of pulmonary neuroendocrine tumours: state of the art and future developments. Cancer Treat Rev 39: 466-72, 2013.

14. Jungraithmayr W, Kayser G, Passlick B, Eggeling S. Neuroendocrine differentiation and neuroendocrine morphology as two different patterns in large-cell bronchial carcinomas: outcome after complete resection. World J Surg Oncol 4: 61, 2006.

15. Paci M, Cavazza A, Annessi V, et al. Large cell neuroendocrine carcinoma of the lung: a 10-year clinicopathologic retrospective study. Ann Thorac Surg 77: 1163-1167, 2004.

16. Grand B, Cazes A, Mordant P, et al. High grade neuroendocrine lung tumors: pathological characteristics, surgical management and prognostic implications. Lung Cancer 81 : 404-49, 2013.

17. Yamazaki S, Sekine I, Matsuno Y, et al. Clinical responses of large cell neuroendocrine carcinoma of the lung to cisplatinbased chemotherapy. Lung Cancer 49: 217-23, 2005.

18. Iyoda A, Hiroshima K, Toyozaki T, et al. Adjuvant chemotherapy for large cell carcinoma with neuroendocrine features. Cancer 92: 1108-1112, 2001.

19. Takei H, Asamura H, Maeshima A, et al. Large cell neuroendocrine carcinoma of the lung: a clinicopathologic study of eighty-seven cases. J Thorac Cardiovasc Surg 124: 285292, 2002.

20. Oshiro $Y$, Kusumoto M, Matsuno $Y$, et al. CT findings of surgically resected large cell neuroendocrine carcinoma of the lung in 38 patients. AJR Am J Roentgenol 182: 87-91, 2004.
21. Yoshida Y, Ota S, Murakawa T, Takai D, Nakajima J. Combined Large Cell Neuroendocrine Carcinoma and Adenocarcinoma with Epidermal Growth Factor Receptor Mutation in a Female Patient Who Never Smoked. Ann Thorac Cardiovasc Surg 22: 1-3, 2013.

22. Battafarano RJ, Fernandez FG, Ritter J, et al. Large cell neuroendocrine carcinoma: an aggressive form of non-small cell lung cancer. J Thorac Cardiovasc Surg 130: 166-172, 2005.

23. Dresler $\mathrm{CM}$, Ritter JH, Patterson GA, et al. Clinical-pathologic analysis of 40 patients with large cell neuroendocrine carcinoma of the lung. Ann Thorac Surg 63: 180-185, 1997.

24. Casali C, Stefani A, Rossi G, et al. The prognostic role of Ckit protein expression in resected large cell neuroendocrine carcinoma of the lung. Ann Thorac Surg 18: 275-290, 2004.

25. Downey RJ, Asakura S, Deschamps C, Colby TV. Large cell carcinoma of the lung: results of resection for a cure. J Thorac Cardiovasc Surg 117: 599-604, 1999.

\section{Correspondence}

Dr. Ozan USLUER

Izmir Dr. Suat Seren Gogus Hastaliklari Hastanesi

35040 Tepecik, Yenisehir

IZMIR / TURKIYE

Tel: (+90-505) 7768059

Fax: (+90-232) 4587262

E-mail: ozanusluer@yahoo.com 